\title{
ON RECENT STUDIES OF RUS' RELATIONS WITH THE TATARS OF THE JOCHID ULUS
}

\author{
Charles J. Halperin
}

\author{
Indiana University (USA) \\ chalperi@iu.ed
}

\begin{abstract}
Research objectives: The goal of this article is to examine recent Englishlanguage publications about Rus' relations with the Tatars of the Jochid ulus in order to correct factual errors and analyze dubious conclusions.

Research materials: The primary materials utilized in this study are three books. The first is Timothy May's new monograph synthesizing the history of the Mongol Empire. The second two are collective works by an international group of recognized specialists. The Golden Horde in World History. A Multi-Authored Monograph is a translation of an anthology originally published in Russian. The Cambridge History of Inner Asia. Volume 2: The Chinggisid Age continues a multi-volume series.

Results and novelty of the research: Recent English-language studies of Rus'-Tatar relations sometimes idealize Rus'-Tatar cooperation. The Rus'-Tatar relationship rested upon destructive conquest and often destructive rule. Much Russian-language scholarship on Rus'-Tatar relations exaggerated the importance of Rus' in the Jochid ulus. In fact the Kipchaks played a far more important role than the Rus'. Some conclusions in recent English-language studies rely upon propagandistic Russian sources, often of later provenance. English-language authors do not always agree with each other, for example, on the level of medieval Rus' culture or the extent of Russian efforts to convert conquered Tatars. Discussions of Noghay's status and offices are very confused. Only a Chinggisid could have issued coinage, so Noghay must have been a Chinggisid. If he was a Chinggisid, he could not have been an emir or ulus beg, offices held by "black bone" commoners.
\end{abstract} Kazan

Keywords: Rus', Jochid ulus, Golden Horde, Noghai, Kipchak khanate, Tatar Yoke,

For citation: Halperin Ch.J. On Recent Studies of Rus' Relations with the Tatars of the Jochid Ulus. Zolotoordynskoe obozrenie=Golden Horde Review. 2020, vol. 8, no. 1, pp. 32-50. DOI: 10.22378/2313-6197.2020-8-1.32-50

In recent decades studies of the Mongol Empire and its successor states have flourished. This essay will examine the conclusions of some recent works. This is not a survey of all scholarship on the subject, nor even a comprehensive evaluation of the works cited, whose quality is not at issue, but a selective analysis of issues that have caught my attention ${ }^{1}$. Timothy May's impressive overview of the Mongol Empire [27] devotes far more attention to the Jochid ulus than the classic study of the Mongols by David Morgan [30] $]^{2}$. Morgan did not find room to comment on either the institutional or cultural history of the Jochid ulus. May successfully integrates the history of the Jochid ulus into his analysis of the Mongol Empire and all its successor states. He has corrected the egregious typographical error in his first

\footnotetext{
${ }^{1}$ Even when the articles and books I cite employ the term "the Golden Horde" I have replaced that anachronism with "Jochid ulus."

${ }^{2}$ For convenience I will use May’s spellings of Mongol names.
} 
book on Mongol military history which turned the site of the first Rus'-Mongol (Tatar) battle from the Kalka River in the Pontic steppe to the Khalkha River in Mongolia $^{3}$. Some of his assertions and conclusions, whether original or derivative of other publications, require correction or merit further discussion.

May writes that in 1234 the (Volga) Bulghars approached some Rus' princes seeking an alliance against the Mongols. He cites the English translation of the sixteenth-century Nikon Chronicle [27, p. 110, citing 54, p. 299, 304]. Neither of the pages he cites pertain to 1234: the first describes events in 1229, the second 1231, and neither mentions the Bulghars at all. May correctly cites the Nikon Chronicle entry sub anno 1236 which does describe the Mongol conquest of Grand Bulghar, but does not mention any attempt by the Bulghars to solicit Rus' military assistance [54, p. 307] ${ }^{4}$. I do not know on what source May based his invocation of a proposed Rus'-Bulghar alliance 5 .

May writes that under Qa'an Möngke silver coinage was uncommon in Rus' where furs became the alternative form of payment of the Mongol tribute [27, p. 155]. This observation is not wrong, but it is inadequate. It is true that no Rus' polity issued its own coinage from the time of the Mongol conquest until at least a century later, and that furs were sometimes used as currency. However, parts of Rus' involved in the Baltic trade did import European silver coinage, even if it is difficult to judge how extensively they were used. Overall silver bars (ingots) served in lieu of minted coins. The Rus' began paying tribute to the Great Mongol Empire soon after conquest, presumably after the first census, and continued paying it to the Jochid ulus in the second half of the thirteenth century. However, no sources communicate how much the Rus' paid or how they paid it until the second half of the fourteenth century, at which time we have numbers in rubles, although their interpretation is contested. At no time did any Rus' principality or even the later Muscovite state mint a coin called the "ruble." The ruble was a denomination of account only; in the sixteenth century it took either 100 or 200 smaller coins (later called kopecks) to constitute a ruble. It is not impossible that in the thirteenth century the Rus' paid tribute in furs of value equivalent to a certain number of rubles, but we can only infer whether this actually took place.

All specialists in the Mongol Empire know that the term "the Golden Horde" was not contemporary to the Jochid ulus, but was invented by Muscovites in the sixteenth century. Some - perhaps most, and certainly almost all when addressing general audiences - use the term anyway. A different term in English for the Jochid ulus has gained currency of late, namely the Kipchak Khanate, a name derived from the geographic base of the Jochid ulus, invariably called the "Kipchak steppe" (Desht-i Kipchak) in oriental sources. May writes that the Jochid ulus was known as the "Kipchak khanate" during the Mongol era [27 p. 280]. This generalization echoes - but does not quote - the same assertion by Donald Ostrowski which popularized the term "the Kipchak Khanate" among historians: "I use the term Qipchak

\footnotetext{
${ }^{3}$ Of course he had corrected this error in other publications before he wrote The Mongol Empire.

${ }^{4}$ I have confirmed the accuracy of the translation [36, p. 104].

${ }^{5}$ István Zimonyi [57, p. 347-355, reprinted 56, p. 25-33] proposed that the Volga Bulghars did not resist Rus' expansion into their territory because they considered the Mongols the greater threat. He does not, however, mention any overt Volga Bulghar alliance overtures to the Rus' princes.
} 
Khanate to refer to the western-most component of the Mongol Empire because that term, along with Ulus of Jochi, is what it called itself" [32 p. xiii]. Ostrowski rightly notes that the Rus' sources most often called the Jochid Ulus "the Horde" (Orda), although they were familiar with the term "ulus". As far as I know, the Rus' sources never use the term "Kipchak steppe". They refer instead to the steppe literally as the "field" (pole) or the "wild field" (dikoe pole), but never the "Kipchak field" (polovetskoe pole). Late literary works reference the "Kipchak Land" (polovetskaia zemlia), or even the "Tatar Land" (tatarskaia zemlia), a projection of a Rus' system of political and geographic nomenclature [12]. How do we know that the Mongols of the Jochid ulus called their polity "the Kipchak khanate"? I have never seen a quotation from an Arabic, Persian, or Turkic source to the phrase "Kipchak Khanate." The Mongols repeatedly emphasized that the Kipchaks were their slaves. The likelihood that they would name their policy after the Kipchaks strikes me as problematic. The term "Kipchak Khanate" is an artificial inference from a geographic term unsupported by any contemporary sources. Spain is located on the Iberian Peninsula, but the medieval kingdoms of Castile and Aragon were not called "the Iberian kingdoms." May is merely following current practice primarily among specialists in medieval Rus' and early modern Russia in referring to the Kipchak Khanate, so his usage may be excused, but not endorsed.

May writes that Sarai "boasted an Orthodox metropolitan" [27, p. 288]. The metropolitan was the head of the Rus' Orthodox Church, based, during the Mongol period, successively in Kiev, Vladimir, and Moscow. The Orthodox hierarch in Sarai was a bishop. Metropolitan (at the time metropolitan-designate en route to Constantinople to be ordained) Alexei did visit Sarai, allegedly to cure an ailing khan, but he was not based there.

May refers to "king-maker Noghay" as a "minor Jochid prince, probably born to a concubine" and therefore deprived of any legitimate claim to be khan. He cites István Vásáry's monograph on the military history of Kipchaks (Cumans) and Mongols in the Balkans [27, p. 289, citing 48, p. 71]. He provides additional evidence on this matter, namely that Noghay issued his own coins from at least 1286, and that the Rus' sources refer to him as khan (tsar'), perhaps only as an inference from the political situation [27, p. 290, 291]. Finally, he suggests that "Noghay's questionable ancestry may have helped to blur the distinction between qarachu ("black bone commoners") and Chinggisid" [27, p. 341-342].

Noghay's power and influence, his use of puppet khans and then assertion of his own status as khan, are not in doubt, but several important questions about Noghay's status remain highly contested: was he a Chinggisid, if so was he the son of a concubine, if he was the son of a concubine was he barred from ascendance the throne of a khan, and what title other than "khan" was and/or should be applied to him. The choices are emir, ulus beg or karachi beg, bekliaribek (beylerbey), or tümen-ü noyad (commander of a tümen, in theory 10,000 troops, in Russian temnik, commander of a t'ma)".

The strongest evidence that Noghay was not a Chinggisid has always been the existence of two different genealogies of his descent ${ }^{6}$, a fact not always adduced in discussions of the issue. The Mongol attention to - nay obsession with - Chinggi-

\footnotetext{
${ }^{6}$ This was how Larry Moses explained the matter to me.
} 
sid genealogy requires no argument; the one thing that Chinggisids presumably would never get wrong was descent in the Golden Kin (Altan uruk). On the other hand, no one doubts that Toqtamysh was a Chinggisid, and he also possesses one genealogy too many, that is to say, two [42, p. 138-144; 51, p. 429], so perhaps deduction might be an insufficient foundation on which to base conclusions. I would be inclined to argue that the Rus' sources would never get Chinggisid status wrong, because that could be a fatal mistake, but that would apply only to contemporary references. Unfortunately, the dating of contemporary Rus' sources rests on quicksand. Later Muscovite sources did wrongly assign Mamai the status of khan, ergo Chinggisid.

In the monograph cited by May, Vásáry describes Noghay as a Chinggisid, great-grandson of Jochi. "Though all the sons of a Chinggisid prince were considered legitimate in the Tatar-Turkic world, only those born to legal wives were given appanages (ulusy) and could become khans. Probably [my emphasis - CJH] that is why Nogay is mentioned in most sources only as a commander-in-chief and "head of ten thousand people"" (Turkic tümen beg, Russian temnik) [48, p. 71]. Note that May glosses "not a legal wife" as a "concubine," a word Vásáry does not use. Note also that Vásáry's use of "probably" almost certainly derives from the absence of any direct reference to Noghay as the son of a concubine. The status of Noghay's mother is an inference.

Supposedly Toqtamysh called both Mamai and Tamerlane "black-bone" men, that is to say commoners, non-Chinggisids [29, p. 694], but apparently no one called Noghay a commoner. Still, Vásáry did not classify Noghay's mother as a concubine (using May's vocabulary for convenience) in all his discussions of Noghay's status. It does not appear in his contributions to two multi-authored volumes on Mongol history and the history of the Jochid ulus. In one Vásáry wrote that the emir Noghay, himself a Jochid, formally only a tumen beg (commander of 10,000), adopted the title of khan at the end of his life, but was considered a usurper, but Vásáry does not elucidate why Noghay was considered a usurper [49, p. 77]. In the other Vásáry wrote that Emir Noghay was Chinggisid. The decisive evidence is that he issued his own coinage and founded his own khanate. "At most he could be considered illegitimate", he again wrote, but without specifying why he should be considered illegitimate [50, p. 531, 535]. The issuance of coinage deserves to be the decisive argument. No non-Chinggisid Mongol, certainly not at the turn of the fourteenth century, would have dared to violate the exclusive prerogative of the Golden Kin to issue coinage. Even Mamai, in the midst of the "great troubles" in the Jochid ulus of the 1360s and 1370s, never issued coinage in his own name; only his puppet khans had coins minted with their names. Noghay's Chinggisid status should be considered settled.

Why most sources, in Vásáry's estimation, failed to call Noghay a khan or sultan but referred to him only as a commander of an army or a tumen, remains to be determined. Ignorance can be excluded: the Jochild ulus and the Ilkhanate were intimate enemies, and the Jochid ulus and the Mamluk sultanate, if not intimate friends, then at least in the period of Noghay's ascendency, extremely wellacquainted. Nor can Ilkhanate hostility be at issue. Perhaps this pattern need not reflect on Noghay's mother or Noghay's legitimacy. Noghay was a commander-inchief or of a tumen and did not occupy a throne. There was little need for foreign sources to identify him by more than his military rank. 
But that still leaves open the issue of his mother's possible concubine status. Anne Broadbridge adduces highly significant evidence on the Mongol and Chinggisid attitude toward concubines. Lineage was only patrilineal, so Noghay would be considered a Chinggisid regardless of the status of his mother, but the status of a male Chinggisid's mother did affect his status. The son of his father's main wife would outrank the son of a lesser wife, and all sons of wives would outrank all sons of concubines. According to Broadbridge, although Carpini declared that there was no distinction between sons of wives or concubines, Marco Polo noted strict primogeniture in Qubilai's family. Lesser sons (whose mothers were concubines) had careers, but careers commensurate with their lesser status. Herbert Franke declared that nomadic children of wives and concubines had equal status, but this contradicts specific Mongol examples. Morris Rossabi acknowledged that children of lesser wives or concubines received lesser inheritance. George Zhao cited the Yuan shi provision that "sons of concubines should not [my emphasis $C J H]$ inherit the throne", but one way or another that proscription was violated in the Ilkhanate. Ilkhans Ghazan and Arghun were both sons of concubines, which Broadbridge declares makes them anomalous, a "puzzle" that "certainly requires attention" [4, p. 32, n. 126, 163, 252-253, 273, 283-284]. Obviously, at least in practice, a Chinggisid born of a concubine mother was not irrevocably barred from succession to the Ilkhanate throne. One might argue that Ilkhanate examples do not have probative value in the Jochid ulus, but the extensive contacts between them, hardly confined to warfare, certainly permit drawing the inference that the Jochids knew about the status of Ghazan's and Arghun's mothers, yet did not bring that issue into play in their war propaganda. Consequently the Jochids did not dispute the Ilkhanate's attitude toward sons of concubines.

Peter Golden supplies earlier steppe precedents both ways concerning maternal versus paternal dynastic legitimacy. A son of Türk Qaghan Muqn was prevented from attaining the Qaghanate because his mother was of "low birth". However Ashina, the eponymous founder of the Türk royal house, was the son of a concubine $[10$, p. 110, n. 7].

Certainly Noghay's delay in claiming to be a khan might derive from his status as a lesser prince born of a concubine, a circumstantial argument, although it could just as easily derive from purely political considerations of the balance of power. We lack sufficient evidence to decide. Leaving that issue aside, the question of Noghay's offices and rank apart from that of khan or Chinggisid non-khan remains.

Different historians assign a panoply of offices and ranks to Noghay. Vadim Trepavlov confines himself to calling him a Jochid. Boris Cherkas cites (Rus') chronicles that call him "tsar" (khan) and himself calls Noghay beylerbey. Roman Pochekaev calls him the great-grandson of Batu and a beklyaribek but adds that he was so powerful that he claimed the throne "in breach of all the principles and rules of the Mongol Empire's law". Pochekaev does not identify those "principles and rules". Emil Sedaliyev calls Noghay a beklyaribek. Although Noghay was called a temnik (head of a tumen), he actually commanded the entire army, not just a tumen. Aleksandr Uzelac confines himself to family matters, calling Noghay a cousin of Khan Mengu Timur. Emma Zilivinskaya and Dmitry Vasilyev call Noghay beklyaribek. Uli Schamiloglu, by contrast, calls Emir Noghay a tribal leader. 
Vladislav Gulevich sticks to a Jochid [44, p. 149, 157-158; 6, p. 157-158; 33, p. $228,230,232 ; 43$, p. $259 ; 47$, p. $380 ; 55$, p. $648 ; 41$, p. $676 ; 11$, p. 757$]^{7}$.

The lack of consistency or consensus among scholars about Noghay's rank and office in part reflects a source problem: No Jochid ulus sources, specifically chronicles, exist which would definitively attest to Noghay's status. All historians rely on Arabic and Persian sources, which, no matter how well-informed, were still written at some distance from the site of events, and not in the current language (Turkic) of the Jochid ulus.

If Noghay was a Chinggisid, there is no problem whatsoever with his commanding a tumen or an entire army; Chinggisids could do that, indeed, Chinggis commanded armies. If Noghay was a Chinggisid who did not occupy a throne then the oriental sources should have called him a sultan, and the Rus' sources should have called him tsarevich; it would appear that neither the former nor the latter did so. However, it is difficult not to imagine that ascribing the title of "emir" or "beg" to Noghay would have been an enormous insult, disrespecting his membership in the Golden Kin. The possibility might be explored that sources who accord him that title were ignorant of his Chinggisid status. Noghay as an ulus beg or beklyaribek/beylerbey is more complicated. If the four ulus begs were clan-tribal heads, the status Schamiloglu ascribes to them, then no Chinggisid could hold that office, unless we modify Schamiloglu's chronology to allow that clan-tribal heads did not occupy all posts of ulus begs until, for the sake of argument, the reign of Uzbek. That ulus begs constituted karachi begs creates another far more serious and unsolvable anomaly. No Chinggisid could be a karachu beg, ever. Ergo, if Noghay was an ulus beg, then at that time ulus begs were not karachi begs. If the beylerbey/beklyaribek was one of the ulus begs, then, again, Noghay cannot have held that office if the ulus beks were clan-tribal leaders or karachi begs. If the office of ulus begs did not become the exclusive prerogative of the clan-tribal leaders, then May's last observation must be reversed: After Noghay the distinction between Chinggisids and black bone commoners became greater.

Even allowing for the notorious flexibility of most medieval terminology, the vocabulary applied to Noghay is extremely confused, if not downright careless. Playing Devil's advocate I would propose that the role of khan-maker was unofficial and bore no specific title. As a Chinggisid Noghay could command a tumen or an army or he could be a governor or some kind, but he could not be an emir, an ulus beg / karachi beg, or beklyaribek/beylerbey. Applying the last title to him was an attempt, albeit an ignorant attempt, by foreign chroniclers to formalize Noghay's informal status as power-behind-the-throne. We may now return to May's other comments on the Jochid ulus.

According to May, in 1322 Shevkal sought to rule Tver directly and to convert its citizens to Islam [27, p. 299]. If true, that would be the only instance in nearly 250 years of Mongol rule over Rus' that a Mongol sought to occupy a Rus' throne, and the only occasion in nearly 150 years since the "official" conversion of the Jochid ulus to Islam under Uzbek that a Tatar tried to impose Islam on Orthodox East Slavs. It was neither. The chronicle tale of the events in Tver in 1323 is anti-

${ }^{7}$ I follow the spellings that appear in this volume. 
Tatar propaganda, probably of Orthodox Christian monastic origin, and nothing more $[18, \text { p. } 93-102]^{8}$.

Concerning the battle of Kulikovo Field in 1380, May writes that "The Russian sources depict an epic victory, which threw off the oppression of the Mongol Yoke and liberated Russia". He then impugns the veracity of that portrayal of the battle by invoking Ostrowski's argument that Donskoi's army, returning from Kulikovo, according to two German chronicles, was later mauled by Mamai's Lithuanian allies, which not every specialist in early Muscovite history finds credible. May also notes that Timur, who was not a Chinggisid, did not attempt to occupy the throne the way Noghay and Mamai did [27, p. 304]. Only one of the three sources of the Kulikovo cycle is an epic and could present the battle as an "epic" victory; even its image of the battle resembles a defeat because of the emphasis upon the scale of Muscovite casualties. Regardless, not one source about the battle mentions the "Mongol Yoke" (Tatarskoe igo), a phrase that does not occur in an East Slavic source until the seventeenth century. Moreover, Mamai did not attempt to seize the throne. One Muscovite source accused him of doing so in order to discredit him [18, p. 108-116]. If Noghay was a Chinggisid, then his ambitions to be khan cannot be equated with those of Mamai or Timur.

Finally, May observes that because in the sixteenth century the Nogai Tatars addressed Ivan IV as the White Tsar, Ivan could be considered qarachu [27, p. 342]. This conclusion does not follow. The Nogais ascribed to Ivan the status of a Chinggisid khan when they praised him as a descendant of Chinggis. Again, a Chinggisid could hardly be "black bone" or hypothetically one of four karachi begs [13, p. 481-497].

The second volume of The Cambridge History of Inner Asia is entitled The Chinggisid Age.

Vásáry's chapter, previously cited for his views on Noghay, contains prose about the Mongol conquests that one does not expect from a Turcologist and Inner Asianist. The Mongols in Hungary (granted, the author is Hungarian, but even so) "massacred, butchered, and ravaged the country "in their fury" [49, p. 71-72]. Turning to the Jochid ulus, Vásáry writes that Russia suffered longer from the influence of Tatars than China or Iran, and that Russian civilizing influence scarcely reached the nomadic Tatars. In 1380 St. Sergei (Sergius) of Radonezh supported Donskoi's campaign against Mamai, but Russian hopes to overthrow the Tatar Yoke were quashed in 1382 when Toqtamysh reasserted Mongol authority by sacking Moscow [49, p. 74, 81, 82] $]^{9}$.

Again, Muscovite sources about the battle of Kulikovo could hardly express hopes for liberation from the "Tatar Yoke" when that term had not yet been invented. The role of St. Sergei of Radonezh in assisting Donskoi is a later literary invention. In lamenting how long Russia "suffered" under the Mongols and the weakness of Russian "civilizing" influence on the nomadic Tatars, Vásáry seems to be following the well-trod anti-Mongol, anti-nomad prejudices of the "patriotic Russian historiography" that he takes to task for distorting history [49, p. 81, n. 45].

${ }_{9}^{8}$ May's bibliography contains this book.

${ }^{9}$ In 2009 Vásáry still referred to a volume co-edited by Uli Schamiloglu and Timur Kocaoğlu as "forthcoming". This was intended to be an anthology of papers from the 2005 Istanbul conference on "The Golden Horde and its Successors", but it never appeared. 
Arsenio Martinez calls attention to the growing gap between conquerors and conquered in the Jochid ulus that accompanied Islamization. In 1275 Qubilai ordered a census and conscription in Russia for troops to fight the Song. The descendants of the sizable number of deportees wound up in Yuan emperor Togh Temur's bodyguard. 'Even when the 'Great Trouble' came belatedly to Russia, the princes did not throw off the 'Mongol Yoke' "because they needed the Horde's support against the expansive Polish-Lithuanian state with its superior army, which had adopted the tactics of its traditional enemies, the Teutonic Order". "In Russia the impossibility of effective opposition caused a withdrawal of disaffected elements from both nomadic and sedentary populations into inaccessible defensive areas, [which] the regime may have permitted because it separated potential rebel leaders from their natural following - marginal elements of both societies formed Qazak or Cossack bands". Darugha and basqaq were Turkic and Mongol terms meaning "oppressor" or "enforcer". When Grand Prince Ivan Kalita of Moscow received the right to farm Jochid ulus taxes, this constituted the "beginning of reunification of Russia". Converting tax farming from Muslim to native Christian hands was greatly facilitated by the "progressive commutation of taxes in kind to cash revenues as a result of a general monetarization of the Horde's and the Russian principalities' economies that was the result of the shift in interregional trade to the Golden Horde in the second quarter of the fourteenth century" [25, p. 93-96, 99-100].

To argue that Islam divided the conquerors and the conquered in the Jochid ulus treats the East Slavs of the forest zone as the only conquered people, whereas Islamization united the Mongol conquerors with the subject population that mattered the most to them, the Kipchaks of the steppe, who adopted Islam along with the Mongols, and to urban Muslim populations in Khwarezm and Bulghar. We have no direct evidence of conscription of troops by the Mongols (as opposed to demanding Rus' princes and their retinues accompany Mongol armies on campaign), and there is a considerable time gap between when Martinez supposes Rus' were drafted, in 1275, and the references to the Rus' regiments in Yuan China. Even during the "Great Troubles" the Rus' princes did not overthrow the "Mongol Yoke" because they had not heard of a "Mongol Yoke" and would not do so until well after Mongol rule had been overthrown. In this period Muscovy did not fight the Polish-Lithuanian state, just the Grand Duchy of Lithuania, whose armies did engage in chronic warfare against the Livonian Knights. However in the fourteenth and early fifteenth century Lithuanian military superiority over Muscovy did not derive from Lithuanian heavy cavalry but from a superior territorial and tax base from which to raise troops. Without adopting heavy cavalry, the Muscovites gained military superiority over Lithuania by the end of the fifteenth century. The earliest references to Cossacks, at first almost exclusively Mongol, then mixed Mongol and Slavic, date to the middle of the fifteenth century. The Tatar and Rus' polities did not "permit" this development of disaffected elements in order to get rid of potential rebels and their supporters; rather, by that time the soon-to-be successor states of the Jochid ulus lacked the ability to control the evolution of Cossack societies, and so did the Rus' principalities. The words daruga and basqaq are commonly thought to derive from a root meaning "to stamp", as in: to put a stamp or seal on a document. I have not seen these terms translated as "oppressor" or "enforcer". To speak of the "reunification" of Russia in the early fourteenth century is highly anachronistic. "Russia" had not been unified on the eve of the Mongol conquest. 
What Kalita's coup in taking over tax farming did was facilitate Muscovite expansion, which was later retroactively conceived of by Muscovite ideologues and later nationalist historians as "unification". Although the significance of trade to the economies of Rus' and the Jochid ulus is unquestionable. I do not know how to measure the monetarization of the Jochid ulus. I do know that no northeastern Rus' principality began minting coins until the third quarter of the fourteenth century, so to speak of monetarization in the second quarter of the fourteenth century sounds premature. Certainly much of the Rus' economy in the second half of the fourteenth and throughout the fifteenth century did not rely on coinage.

Golden and Trepavlov indicate that initially the Jochid ulus was called the Ulugh ulus, the Great Horde [10, p. 114; 45, p. 767]. Without questioning the validity of that assertion, it is worth noting that the Rus' sources did not use that term for the Volga Horde. They employed it for the nomadic remnant of the Jochid ulus after its fragmentation in the middle of the fifteenth century. It is not impossible that this title was in Tatar eyes historical, but in Rus' sources it was new.

Thomas Allsen refers to the "Tartar Yoke" in quotation marks, perhaps to signify that it is an anachronism, but he does not call attention to, let alone explicate, the misspelling of "Tatar" as "Tartar" [2, p. 135]. He concludes that the Orthodox Christian cultural empire ${ }^{10}$ did not participate in cultural development in the Jochid ulus at same level as the Sinitic and Islamic cultural empires did among the Yuan and the Ilkhanate. This relative failure among other causes was the product of a social contrast. Whereas the Yuan and Ilkhanate Mongols lived with their subjects, the Mongols of the Jochid ulus remained in the steppe and ruled "the most populous sedentary principalities, by a kind of 'remote control"'. At a more fundamental level, Rus' and the Jochid ulus possessed unequal cultural assets. The Mongols needed East Slavic military recruits and artisans "but there were no astronomers/astrologers, physicians, geographers, cartographers and mathematicians" in Rus', at least not of the status of the scholars and professionals in China or Iran. There was no pool of administrative personnel in Rus' whom the Mongols of the Jochid ulus could recruit. Like the Alans, Rus' only sent contingents of troops to China, not scholars $[2, \text { p. } 143]^{11}$.

Allsen echoes the line of reasoning of Martinez which presupposes that the most important conquered people in the Jochid ulus were the forest-dwelling Rus', the subjects among whom the Mongols of the Jochid ulus did not live, but Allsen turns the consequences of this uncontested feature of Jochid ulus society upside down from Vásáry. To Allsen the Rus' exercised less civilizing influence on the Jochid ulus Mongols because they had less civilization themselves. They could offer the Mongols neither professional administrators nor scholars. To me Allsen misses the point. The administration of the Jochid ulus seems not to have suffered from the absence of talented Rus' officials for the same reason that it did not lack for cultural achievement. The culture of the Jochid ulus became Islamic, and its scholars, poets, architects, and officialdom could draw upon the internal resources of Islamic Khwarezm and Bulghar, and the external resources of Asia Minor, Egypt and even

${ }^{10}$ By this term Allsen means what has been called the Byzantine Commonwealth, the cultural world encompassing the Byzantine Empire and the Orthodox Slavs.

${ }^{11}$ For some reason Allsen alludes to Georgia as if it were part of the Jochid ulus, instead of a vassal of the Ilkhanate. 
Iran. Allsen reverses Pushkin's famous aphorism that the Mongols, unlike the Arabs, brought to the peoples they conquered neither Aristotle nor algebra by emphasizing what cultural skills the Rus' could not share with the Mongols.

Christian Noack discusses the Muscovite conquest of the middle Volga region, the khanates of Kazan and Astrakhan, in the sixteenth century. According to Noack, after Ivan IV's failure to impose a puppet on Kazan, he resolved upon methods "that violated the established rule of steppe diplomacy and traditional clientele policy pursued by his ancestors from the 1480s onward" by imposing outright conquest. Ivan IV had to overcome "the reluctance of his own service nobility" and to "ignor[e] the advice of some war-weary boyars". "Ivan IV's campaigns against Kazan had been conducted with missionary zeal and the Orthodox Church was instrumental in providing additional spiritual and political justification for the transgression of the traditional rules of steppe policies. After all, with the recurrent technique of indirect rule failing, Ivan had betrayed political customs already with the annexation of the right bank of the Volga River in 1551 - foreign territories that had never belonged to the Eastern Slavic principalities. The chronicles, though, suggested the opposite and depicted the Middle Volga as a constituent part of Kievan Rus' allegedly settled by Orthodox Slavs". "Against all historical evidence, Ivan claimed the 'Kazan yurt' as his patrimony, and referred to the fact that already his grandfather Ivan III had invested rulers there". Religious arguments about the defense of the (Russian) fatherland "hardly veiled the aggressive character of Ivan's policy" but the need to free Russian captives in Kazan was more plausible. The repetition of these arguments shows that the "motive for conquest was perceived as being far from self-evident". The development of imperial doctrine and autocracy was "intrinsically linked" to the Byzantine concept of the basileos and the doctrine of Moscow, the Third Rome. Ivan sought to overcome the customary limits on royal authority, such as the need for consultation with the boyars. Sixteenth-century Muscovite diplomacy "paid lip service" to Chinggisid dynastic superiority [31, p. 305-308].

That Ivan III selected and invested rulers in Kazan constitutes valid historical evidence that Kazan had acknowledged its subservience to Moscow. Whether such transient dependence rendered Kazan Ivan IV's yurt and patrimony is another matter.

Ivan IV did implement a new policy toward Kazan, but only after the old policy had failed, as Noack concedes, to eliminate Kazan slave-trading, although it must be said that after conquering Kazan, the Muscovites enslaved many Kazan Tatars, so there is no question of moral superiority here on the slavery issue. Not all historians agree that the slave-trade was a major segment of the Kazan economy [1, p. 778]. Noack's analysis is suspect on different grounds. Clearly Noack idealizes "traditional steppe diplomacy". The Great Mongol Empire, like the Jochid ulus, was not founded by the "traditional steppe diplomacy" of consent and consultation, but by conquest, so his judgmental use of words like "transgression" and "betrayed" rings false. Judging the sincerity of religious justifications for military aggression is hardly profitable; all medieval and early modern armies invoked God as they marched out. Chinggis invoked Tengri, the Great Blue Sky. It is also true that Muscovites invented historical justifications for conquering Kazan, but only one source, not a chronicle but a history, the Kazan History (Kazanskaia istoriia) claimed that Kazan had been settled by East Slavs, as explicated in Jaroslaw Pelenski's monograph that Noack cites. However, I know of no evidence that the 
service nobility were "reluctant" to conquer Kazan; some servitors claimed they could not afford to go on campaign, but Ivan supplied them with the necessary provisions and they happily marched off to Kazan to conquer and returned with slaves and booty. No sources attest to "war-weary boyars". The historiography mentions boyars who supposedly opposed Ivan IV's war against Livonia, a separate matter, but no one in Muscovy opposed the conquest of Kazan. Despite the Russian Orthodox Church's support for the campaign, after conquest even it realized that "missionary zeal" would be counter-productive, so attempts to convert the Muslim Tatars to Orthodox Christianity were not pursued [39, p. 511-540]. After publication of The Cambridge History of Inner Asia volume 2, the significance of the concept of autocracy for Ivan IV's ideology was questioned [14, p. 197-213], but even by 2009 many specialists had noted that the concept of Moscow, the Third Rome was conspicuous by its absence from all ideological expressions during Ivan IV's reign [5, p. 355-376]. In theory Ivan IV objected to the requirement of Muscovite political custom that he consult his boyars, but in practice he always had boyar advisors. Sixteenth-century Muscovite diplomacy did far more than pay lipservice to Chinggisid legitimacy, as demonstrated by the deference shown to the Gireid khans of Crimea, the use of puppet khans in Kasimov and Kazan, and Ivan IV's choice of a converted Chinggisid, Simeon Bekbulatovich, to occupy the throne of Moscow after Ivan IV "abdicated" in 1575 [17, p. 306-330].

The second collective work, The Golden Horde in World History, is devoted exclusively to the Jochid ulus.

Vladimir Ivanov observes that because of warfare and Kipchak alienation from sedentary objects there was no Rus'-Kipchak trade. No Rus'-crafted objects can be found in Polovtsy burial sites [22, p. 47]. However, various steppe peoples contributed to the "Black Caps" (Chernye klobuki), who served as vassals of the Kievan Rus' princes, different Kipchak groups served as mercenaries for or allies of various Rus' principalities, and some Rus' princes intermarried with the Kipchaks. Such developments suggest that warfare and animosity did not entirely characterize Rus'-Kipchak relations. Regardless of the archeology, the Hypatian Chronicle sub anno 1185 mentions Rus' merchants returning from a Kipchak camp [36, p. 634$635]^{12}$. Without question the Kipchaks extracted "customs" from Rus' commercial caravans crossing the steppe, when they did not attempt to rob them outright.

Pochekaev asserts that for Rus' princes walking between two fires as a purification test before appearing before a Jochid ulus khan was not mandatory. The Tatars made Michael of Chernigov do it because if he refused, as they expected and as he did, it would provide an excuse to execute a political enemy of the Mongols. On the other hand, the Mongols exempted Daniil of Halych from performing the ritual [35, p. 189]. I would contend that in his time Daniil was as hostile to the Mongols as Michael. Given the hostility of the chroniclers toward the Mongols and the discretion they sometimes manifested in narrating Rus' princely encounters with "infidels," it strikes me as more likely that Daniil was not exempt from the two fires but that the chronicle chose not to mention his performance of the rite. The fact is that the sources mention the two-fire ritual only for Michael of Chernigov; it is difficult to believe that all other Rus' princes were exempted.

\footnotetext{
${ }^{12}$ Peter Golden kindly called my attention to this entry.
} 
In another article Pochekaev writes that the princes of Moscow conquered almost all of Northeast Rus', including Novgorod [34, p. 245]. His wording is poorly chosen. Of course Novgorod is located in Northwest Rus', even if it became subordinate to Moscow in Northeast Rus'. Pochekaev proposes that the fact that a yarlyk from Khan Uzbek to the Russian Orthodox Church was forged suggests that Uzbek had issued one, as did every khan [34, p. 247]. I would phrase the matter differently. The fact that someone forged a charter from Uzbek attests that no charter from him was extant, else it would have given the lie to the forgery. In addition the forger must have assumed that his intended audience would believe that Uzbek had issued a charter, a different assumption than that every khan had done so. The number of surviving charters from khans of the Jochid ulus to the Russian Orthodox Church is only a small fraction of the number of charters that would have existed if every khan issued one.

Roman Hautala writes that when Daniil submitted to Batu he accepted "formal dependence ...on condition of maintaining significant autonomy" for GaliciaVolhynia" [20, p. 366]. Given the imbalance of power between Batu and Daniil, Daniil was in no position to impose conditions upon his subordination to the Jochid ulus. Moreover, Daniil's dependence on the Jochid ulus was far from "formal", it was real, involving tribute and military service.

Khatip Minnegulov describes the vibrant literary culture of Kazan on the eve of the Muscovite conquest. The poet and religious activist Qolsarif died unsuccessfully defending Kazan in 1552. Sharifi Jannitarkhani is credited with writing the "Zafar-nama-i Vilayat-i Kazani" ("The story of the victory of the Kazan state"), a prose work with poetic content, in 1550 on the successful defense of the city against the Muscovite army in that year. It called Ivan IV "conceited", a "troublemaker," and a "malefactor", defiantly proclaiming "This is not Ivan's city!". Some scholars identify Sharifi as Qolsarif. One of last poets before the Kazan conquest, Muhammedyar, composed two epic lyric poems with didactic content that dreamt about the qualities of a just ruler, evaluated people by their humane actions rather than their wealth, rank or religion, and valued justice, compassion, generosity, and loyalty. Its ideas are concordant, Minnegulov asserts, with those of the great Renaissance thinkers and West European utopians of the Middle Ages. Despite diplomatic immunity while working as interpreter for Kazan in Moscow he was brutally murdered at Ivan IV's orders. A member of the same delegation, Adnash Hafiz, who was enslaved, wrote the "Luminary of Hearts" on religious and moral questions, a work widely known among Tatars. According to the great Orientalist Vasilii Bartol'd (Barthold), it was originally composed in Arabic but then translated into Farsi and later Turkic, and was based upon multi-lingual sources including the Quran. In addition, literary culture continued after the Russian conquest of all the Tatar khanates, in Crimea and to some extent in Kasimov, despite "very harsh colonial oppression" [28, p. 520-521, 523]. This evidence of Kazan's cultural achievements in general and of literary reactions to the Muscovite conquest in particular deserves inclusion in every history of Ivan IV's reign.

Elmira Sayfetdinova disputes assertions that the Jochid ulus lacked written historiography based upon the fact that only folklore survives from the period of Jochid ulus independence and unity. The high spiritual culture of the Jochid ulus justifies the postulate that such historiography existed. It also demonstrates Tatar cultural development because nomadic civilizations had no written literature. No- 
vels and other literary works with historical content do survive. To be sure, texts of Jochid ulus history date mainly to the "fifteenth to fourteenth centuries" 13 , such as the "Chinggis-name" of the mid-sixteenth century Khiva author Ötemysh Hajji, whose use of the Altan Debter and Rashid al-Din proves that there was systematic historiography in the Jochid ulus [40, p. 524-528]. (Coincidentally, Ilya Zaitsev asserts that although no Tatar work dedicated to the history of Hajji Tarkhan (Astrakhan) survives, one must have existed [52, p. 753].)

The lack of a written chronicle tradition, a single genre of literature, in the Jochid ulus, in no way impairs its other cultural achievements or entails the absence of historical memory expressed in other genres. The development of written chronicles among the successor states of the Jochid ulus may be attributed to varying local conditions. For example, Crimean historiography shows Ottoman influence. On point, no historical work from the Jochid ulus's successor states identifies a written chronicle from the period of Jochid ulus unity. That Ötemysh Hajji utilized Mongolian and Persian sources to write his history attests to the opposite of what Sayfetdinova proposes. His use of non-Jochid sources suggests that he had no earlier works from the Jochid ulus on which to rely ${ }^{14}$.

Zaitsev cites the "Crimean Affairs" (krymskie dela) archival documents in his study of the Astrakhan khanate. Muscovite diplomatic papers use the particle dei to indicate oral communication. The translator of Zaitsev's article neither knew that nor consulted someone who did, so the translation includes dei in transliteration, which is meaningless [52, p. 750-751].

Anvar Aksanov declares that Ivan IV's coronation meant that he was equal to a khan, part of Muscovy's foreign policy of pursuing its "Horde heritage". Prince Andrei Kurbsky compiled the chronograph and was the author of the Kazan History (Kazanskaia istoriia), a history of Kazan from its founding to its conquest by Ivan IV. Official Muscovite chronicles lack credibility. Moscow won the fight for domination of the former Jochid ulus [1, p. 778-779].

Ivan IV's coronation was based upon a Byzantine coronation ordo; it is difficult to see how this could convey the legitimacy of a Chinggisid khan. As discussed above, that Nogai Tatars addressed Ivan IV as "White Khan" does not mean that Ivan IV intended to take over the mantle of the Jochid ulus. He never questioned Crimean pretensions to that distinction. The concept of the Muscovite tsardom as a successor state of the Jochid ulus, which I do not share, has been proposed by a number of scholars in Russia, especially Tatarstan, and the US, for example [38, p. 783-793]. Suffice here to say that this conclusion depends upon how one defines a "successor state" [16, p. 377-387]. Calling the Muscovite chronicles "official" likewise depends upon the criteria utilized to identify an "official" source [19, p. 81-93].

Andrey Belyakov concludes that when Ivan Kalita's heirs began to outrank serving Chinggisids cannot be established with certainty. Chinggisids became approximately equal to West European noble natives like the captive Master of the

${ }^{13}$ Common sense strongly suggest that this should read "fifteenth to sixteenth centuries", but the original Russian text contains the same wording; was this a typographical error that was not corrected in the translation process?

${ }^{14}$ Sayfetdinova does not cite [15, p. 1-15], the most complete discussion of this question, nor does she cite anyone else who disputes the existence of Jochid ulus chronicles. 
Livonian Knights Wilhelm von Fürstenberg, but their higher status was sometimes accompanied by lower material rewards. By the end of Ivan IV's reign, the functional use of the Kasimov Khanate had already been exhausted and it was "liquidated". On campaign Ivan IV consulted his "campaign Duma" (polkhodnaia duma) $[3$, p. 812-814, 816].

In terms of status in Muscovy through the reign of Ivan IV no one outranked Chinggisids, serving or independent, save members of the Muscovite royal family. Political subordination to the ruler of Muscovy did not and could not change that. The special status of members of the Golden Kin could not be translated outside of Muscovite relations with Tatars, so comparing it to that of a Livonian knight is meaningless. The Kasimov Khanate had outlived its usefulness when Muscovy annexed Kazan in 1552, although Kasimov Tatars served in Muscovite armies in the Livonian War that began in 1558 and Muscovite toleration of Islam in the Kasimov Khanate served Muscovite diplomacy with the Ottomans well, because it enabled Muscovy to deprive the sultan of an excuse to launch a holy war against Muscovy. Rakhimzyanov's article details the history of the Kasimov Khanate into the seventeenth century. While Ivan was accompanied by boyars on campaign and did consult them on the road, there were no institution called the "campaign Royal Council" 15 .

In another article in the anthology Zaitsev writes that while in the thirteenth century refusing to fight the Mongols, the Scourge of God, was considered a sign of true Christian humility on the part of Rus' princes, especially as the Orthodox Church hoped to convert the pagan Tatars, by the fourteenth century probably failure to fight Muslim Tatars was considered cowardice. Agreeing with Aksanov and Rakhimzyanov, Zaitsev observes that the Muscovite state "is believed to have been the successor of the Empire of the Chinggisids", although it did not attempt to convert Muslims, a sign of its Eurasian continuity, in contradistinction to Noack's implication [53, p. 868].

Zaitsev's contrast of Rus' attitudes toward the Tatars in the thirteenth and fourteenth centuries in too logical. In the thirteenth century Rus' princes who died fighting the Tatars, despite the view that their incursion was God's punishment for Rus' sins, were considered martyrs, although princes who submitted were considered humble and princes who just ran away, doing neither, were not criticized for it. Zaitsev does not specify who "believed" that Muscovy was a successor state of the Chinggisid Empire; I would contend that it was not the Muscovite Court ${ }^{16}$.

Dariusz Kolodzijczyk asserts that Mamai let Algirdas annex Eastern Podolia and the Kiev region (Kievshchina) because they shared a common enemy, namely the Muscovite Grand Principality, and in exchange for taxes, which Lithuania was still paying forty years later [24, p. 893].

It is of course true that Lithuania humored Jochid ulus sensibilities by paying tribute and taxes for these East Slavic territories after their annexation, but Mamai did not "let" Algirdas conquer them. At the time Mamai simply did not have the means to prevent their conquest by Lithuania, and he made the best of a bad situation. Because Lithuanian eastward expansion cannot be dated exactly, it is not even certain that Mamai and Moscow were at odds at the time.

\footnotetext{
${ }^{15}$ The translator of Belyakov's article renders deti boiarskie literally as "boyar children"; it means "gentry" [2, p. 820].

${ }^{16}$ The translator renders Trebnik as "Book of Needs" which is literal but uninformative; it is a ritual book of prescribed prayers, a book of devotion [53, p. 869].
} 
Trepavlov's "Conclusion" claims that the system of government of the Jochid ulus had a "significant impact" on the statehood and culture of the Rus' principalities. Furthermore, the "nationhood of the Ulus of Jochi demonstrates a quite rare historical example of a long-term, conflict-free coexistence over a large territory between subjects belonging to different economic spheres (nomadic cattle-herders and sedentary farmers), adhering to different religions, and speaking different languages" [45, p. 921].

I would not dispute the political influence of the Jochid ulus on the Rus' principalities, but their concept of "statehood" and culture owned much more to the Kievan Rus' than to the Tatars. Gosudarstvennost' in the Russian original should not be translated as "nationhood"; it derives not from the word for "nation" (narod), but from "gosudarstvo" meaning "state," ergo "statehood," or "concept of state". But even in a revised translation Trepavlov's obiter dictum presents a highly idealized distillation of Rus'-Tatar relations. Yes, there was more pragmatic cooperation than the dominant paradigm of "the Russian national struggle against the Tatar Yoke" allows, but in its broader context we are still dealing with conquerors and conquered in a relationship in which the former always had ready and ruthless recourse to coercion to achieve its goals. There is no need to sugar-coat history.

These critical comments are intended only to further discussion of the complicated relations between the Rus' and the Mongols of the Jochid ulus and its successor states. They are matters for discussion. All the authors cited here are to be thanked for making valuable contributions to historical knowledge.

\section{REFERENCES}

1. Aksanov A. Vilayate Kazan (The Kazan Khanate). The Golden Horde in World History. A Multi-Authored Monograph. Kazan: Sh. Marjani Institute of History of the Tatarstan Academy of Sciences, 2017, pp. 772-783.

2. Allsen T.T. Mongols as Vectors for Cultural Development. The Cambridge History of Inner Asia, vol. 2, The Chinggisid Age, pp. 135-154.

3. Belyakov A. Tatars in the Muscovite State. The Golden Horde in World History. A Multi-Authored Monograph. Kazan: Sh. Marjani Institute of History of the Tatarstan Academy of Sciences, 2017, pp. 811-828.

4. Broadbridge A.F. Women and the Making of the Mongol Empire. Cambridge: Cambridge University Press, 2018. xxii, 321 p.

5. Bushkovitch P. The Formation of National Consciousness in Early Modern Russia. Harvard Ukrainian Studies 10, 1986, pp. 355-376.

6. Cherkas B. Territorial Organization of the Ulus of Jochi (Territory to the West of the Don). The Golden Horde in World History. A Multi-Authored Monograph. Kazan: Sh. Marjani Institute of History of the Tatarstan Academy of Sciences, 2017, pp. 153-175.

7. Curta F., Maleon B.-P. (ed.). The Steppe Lands and the World Beyond Them. A Collection in Honor of Victor Spinei On His $70^{\text {th }}$ Birthday. Iasi: Editura universitatii "Alexander Ioan Cruz", 2013. $797 \mathrm{p}$.

8. di Cosmo N., Frank A. J., Golden P.B. (ed.). The Cambridge History of Inner Asia. Volume 2: The Chinggisid Age. Cambridge: Cambridge University Press, 2009. xxvii, 488 p.

9. The Golden Horde in World History. A Multi-Authored Monograph. Kazan: Sh. Marjani Institute of History of the Tatarstan Academy of Sciences, 2017. 968 p. +28 p. with colour insert.

10. Golden P. Migrations, Ethnogenesis. The Cambridge History of Inner Asia. Vol. 2: The Chinggisid Age, pp. 109-119. 
11. Gulevich V. Ulug Ulus (the Crimean Khanate). The Golden Horde in World History. A Multi-Authored Monograph. Kazan: Sh. Marjani Institute of History of the Tatarstan Academy of Sciences, 2017, pp. 756-772.

12. Halperin C.J. The Image of the Mongols (Tatars) as Kipchaks (Polovtsy) in Russian Sources, Thirteenth-Sixteenth Centuries. Archivum Eurasiae Medii Aevi 21, 2014 2015, pp. 137-146.

13. Halperin C.J. Ivan IV and Chinggis Khan. Jahrbücher für Geschichte Osteuropas 51, 2003, pp. 481-497.

14. Halperin C.J. Ivan IV as Autocrat (samoderzhets). Cahiers du monde russe 55, 2014, pp. 197-213.

15. Halperin C.J. The Missing Golden Horde Chronicles and Historiography in the Mongol Empire. Mongolian Studies 23, 2000, pp. 1-15.

16. Halperin C.J. 'No One Knew Who They Were': Rus' Interaction with the Mongols. Florin Curta, Bogdan-Petru Maleon (eds). The Steppe Lands and the World Beyond Them, pp. 377-387.

17. Halperin C.J. Simeon Bekbulatovich and the Mongol Influence on Ivan IV's Muscovy. Russian History 39, 2012, pp. 306-330.

18. Halperin C.J. The Tatar Yoke: The Image of the Mongols in Medieval Russia. Bloomington: Slavica Publishers, Inc. 2009. x, 239 p.

19. Halperin C.J. What is an 'Official' Muscovite Source from the Reign of Ivan IV? Kleimola A.M., Lenhoff G. (eds). The Book of Royal Degrees and the Genesis of Russian Historical Consciousness, pp. 81-93.

20. Hautala R. The Confrontation between the Ulus of Jochi and the Catholic Europe from the Mid- $13^{\text {th }}$ to Mid- $14^{\text {th }}$ Centuries. The Golden Horde in World History. A MultiAuthored Monograph. Kazan: Sh. Marjani Institute of History of the Tatarstan Academy of Sciences, 2017, pp. 364-376.

21. The History of the Tatars since Ancient Times in Seven Volumes, v. III: The Ulus of Jochi (Golden Horde) $13^{\text {th }}$ century - mid $14^{\text {th }}$ century. Kazan: Marjani Institute of History of Tatarstan Academy of Sciences, 2017. 1127, 71 p.

22. Ivanov V. The Nomads of Eastern Europe in the Early $13^{\text {th }}$ Century. The Golden Horde in World History. A Multi-Authored Monograph. Kazan: Sh. Marjani Institute of History of the Tatarstan Academy of Sciences, 2017, pp. 40-49.

23. Kleimola A.M., Lenhoff G. (eds). The Book of Royal Degrees_and the Genesis of Russian Historical Consciousness / "Stepennaia kniga tsarskogo rodosloviia" i genezis russkogo istoricheskogo soznaniia. Bloomington: Slavica Publishers, Inc., 2011. xv, 348 p.

24. Kolodziejczyk D. Relations Between Tatar States and the Polish-Lithuanian State. The Golden Horde in World History. A Multi-Authored Monograph. Kazan: Sh. Marjani Institute of History of the Tatarstan Academy of Sciences, 2017, pp. 892-901.

25. Martinez A.P. Institutional Developments, Revenue and Trade. The Cambridge History of Inner Asia, vol. 2, pp. 89-108.

26. May T. The Mongol Art of War. Yardley: Westholme Publishing, 2007. xiv, 215 p.

27. May T. The Mongol Empire. Edinburgh: Edinburgh University Press, 2018. xxii, $416 \mathrm{p}$.

28. Minnegulov Kh. Literature of the Ulus of Jochi and the Post-Golden Horde Tatar Khanates. The Golden Horde in World History. A Multi-Authored Monograph. Kazan: Sh. Marjani Institute of History of the Tatarstan Academy of Sciences, 2017, pp. 515-523.

29. Mirgaleyev I. Attempts to Restore the Golden Horde at the End of the 14Beginning of the $15^{\text {th }}$ Century. The Golden Horde in World History. A Multi-Authored Monograph. Kazan: Sh. Marjani Institute of History of the Tatarstan Academy of Sciences, 2017, pp. 693-699.

30. Morgan D.O. The Mongols. Cambridge, MA: Blackwell, 1990. xi. 238 p.

31. Noack C. The Western Steppe: The Volga-Ural Region, Siberia and the Crimea under Russian Rule. The Cambridge History of Inner Asia, vol. 2, pp. 303-330. 
32. Ostrowskii D. Muscovy and the Mongols. Cross-cultural Influences on the Steppe Frontier. Cambridge: Cambridge University Press, 1998. xvi, 329 p.

33. Pochekaev R. First Rulers of the Ulus of Jochi. The Golden Horde in World History. A Multi-Authored Monograph. Kazan: Sh. Marjani Institute of History of the Tatarstan Academy of Sciences, 2017, pp. 220-238.

34. Pochekaev R. The Golden Age of the Ulus of Jochi: The Rule of Öz Beg and Jani Beg. The Golden Horde in World History. A Multi-Authored Monograph. Kazan: Sh. Marjani Institute of History of the Tatarstan Academy of Sciences, 2017, pp. 239-259.

35. Pochekaev R. The Law of the Golden Horde. Taxation. Court Etiquette and the Protocol. The Golden Horde in World History. A Multi-Authored Monograph. Kazan: Sh. Marjani Institute of History of the Tatarstan Academy of Sciences, 2017, pp. 175-192.

36. Polnoe sobranie russkikh letopisei [Complete Collection of Russian Chronicles], Vol. 10. Moscow: 'Science', 1965. 244 p. (In Russian)

37. Polnoe sobranie russkikh letopisei [Complete Collection of Russian Chronicles], Vol. 2, Moscow: USSR Academy of Sciences, 1962. xvi, 938, 87 p. (In Russian)

38. Rakhimzyanov B. The Meshchera Yurt' (Kasimov Khanate). The Golden Horde in World History. A Multi-Authored Monograph. Kazan: Sh. Marjani Institute of History of the Tatarstan Academy of Sciences, 2017, pp. 783-793.

39. Romaniello M.P. Mission Delayed: The Russian Orthodox Church after the Conquest of Kazan'. Church History 76, 2007, pp. 511-540.

40. Sayfetdinova E. Formation of the Historiographic Tradition. The Golden Horde in World History. A Multi-Authored Monograph. Kazan: Sh. Marjani Institute of History of the Tatarstan Academy of Sciences, 2017, pp. 524-528.

41. Schamiloglu U. The Impact of the Black Death on the Golden Horde: Politics, Economy, Society, Civilization. The Golden Horde in World History. A Multi-Authored Monograph. Kazan: Sh. Marjani Institute of History of the Tatarstan Academy of Sciences, 2017, pp. 674-688.

42. Seleznev Iui. V. Elita Zolotoi ordy [The Elite of the Golden Horde]. Kazan: FEN, 2009. 231 p. (In Russian)

43. Seydaliyev E. Military Science in the Golden Horde. The Golden Horde in World History. A Multi-Authored Monograph. Kazan: Sh. Marjani Institute of History of the Tatarstan Academy of Sciences, 2017, pp. 259-281.

44. Trepavlov V. The Administrative Structure. Administrative Organization. The Golden Horde in World History. A Multi-Authored Monograph. Kazan: Sh. Marjani Institute of History of the Tatarstan Academy of Sciences, 2017, pp. 144-153.

45. Trepavlov V. Conclusion. The Golden Horde and Tatar Yurts in World History. The Golden Horde in World History. A Multi-Authored Monograph. Kazan: Sh. Marjani Institute of History of the Tatarstan Academy of Sciences, 2017, pp. 919-922.

46. Trepavlov V. The Great Horde. The Golden Horde in World History. A MultiAuthored Monograph. Kazan: Sh. Marjani Institute of History of the Tatarstan Academy of Sciences, 2017, pp. 737-747.

47. Uzelac A. The Golden Horde and the Balkans (13-14 ${ }^{\text {th }}$ centuries). The Golden Horde in World History. A Multi-Authored Monograph. Kazan: Sh. Marjani Institute of History of the Tatarstan Academy of Sciences, 2017, pp. 376-394.

48. Vásáry A. Cumans and Tatars: Oriental Military in the pre-Ottoman Balkans:: 1185-1365. Cambridge: Cambridge University Press, 2005. xvi, 230 p.

49. Vásáry I. The Jochid Realm: The Western Steppe and Eastern Europe. The Cambridge History of Inner Asia. Vol. 2: The Chinggisid Age, pp. 67-85.

50. Vásáry I. Military and Political Contacts with Byzantium and the Balkan Countries. The History of the Tatars since Ancient Times in Seven Volumes, v. III: The Ulus of Jochi (Golden Horde) $13^{\text {th }}$ century - mid $14^{\text {th }}$ century), pp. 530-541. 
51. Vernadsky G. The Mongols and Russia. New Haven: Yale University Press, 1953. $\mathrm{xi}, 462 \mathrm{p}$.

52. Zaitsev I. The Astrakhan Yurt. The Golden Horde in World History. A MultiAuthored Monograph. Kazan: Sh. Marjani Institute of History of the Tatarstan Academy of Sciences, 2017, pp, 747-756.

53. Zaitsev I. Tatar-Russian Relations in the $16-18^{\text {th }}$ Centuries. The Golden Horde in World History. A Multi-Authored Monograph. Kazan: Sh. Marjani Institute of History of the Tatarstan Academy of Sciences, 2017, pp. 863-871.

54. Zenkovsky S.A. (ed.), Zenkovsky S.A., Zenkovsky B.J. (tr.). The Nikonian Chronicle, vol. 2. Princeton: The Kingston Press, 1984. xxxix, 323 p.

55. Zilivinskaya E., Vasilyev D. Cities of the Golden Horde. The Golden Horde in World History. A Multi-Authored Monograph. Kazan: Sh. Marjani Institute of History of the Tatarstan Academy of Sciences, 2017, pp. 630-660.

56. Zimonyi I. Medieval Nomads in Eastern Europe. Collected Studies. Victor Spinei (ed.). Bucureşti: Editoru Academiei Romăne; Brăila: Editura Istros a Muzueului Brăilei, 2014. $398 \mathrm{p}$.

57. Zimonyi I. Volga Bulghars between Wind and Water (1220-1236). Acta Orientalia Academiae Scientiarum Hungaricae 46, 1992/1993, pp. 347-355.

About the author: Charles J. Halperin - Research Fellow of the Russian and East European Institute, Indiana University, Bloomington (Bloomington, Indiana, USA). E-mail: chalperi@iu.ed

Received December 25, 2019 Accepted for publication February 27, 2020

Published March 29, 2020

\title{
О НЕДАВНИХ ИССЛЕДОВАНИЯХ ВЗАИМООТНОШЕНИЙ РУСИ С ТАТАРАМИ УЛУСА ДЖУЧИ
}

\author{
Чарльз Дж. Гальперин \\ Индианский унверситет (США) \\ chalperi@iu.ed
}

Целью данной статьи является рассмотрение недавних англоязычных публикаций об отношениях Руси с татарами Улуса Джучи с целью исправления фактических ошибок и анализа сомнительных выводов.

Maтериаль: основными источниками являются три книги. Первая - новая монография Тимоти Мэйа, в которой синтезирована история Монгольской империи. Вторые две - коллективные работы международной группы признанных специалистов. Золотая Орда в мировой истории. Коллективная монография - перевод антологии, первоначально изданной на русском языке. Кэмбриджская история Внутренней Азии. Том 2: Эра Чингизидов - является продолжением многотомной серии.

Результаты: недавние англоязычные исследования русско-татарских отношений иногда идеализируют русско-татарское сотрудничество. Русско-татарские отношения опирались на разрушительное завоевание и зачастую разрушительное правление. Многие русскоязычные исследования преувеличивали значение Руси в Улусе 
Джучи. На самом деле кыпчаки сыграли гораздо более важную роль, чем Русь, в Улусе Джучи. Некоторые выводы последних англоязычных исследований опираются на пропагандистские русские источники, часто позднего происхождения. Англоязычные авторы не всегда согласны друг с другом, например, в отношении уровня средневековой русской культуры или масштабов русских усилий по обращению завоеванных татар в православное христианство. Рассмотрение статуса Ногая и его должности весьма запутано. Только Чингизид мог чеканить монеты, и поэтому Ногай должен был быть Чингизидом. Если же он был Чингизидом, он не мог быть эмиром или улусбеком и занимать должность, которую занимали простолюдины «черной кости».

Ключевые слова: Русь, Золотая Орда, улус Джучи, Ногай, кыпчакское ханство, татарское иго, Казань

Для цитирования: Halperin Ch.J. On Recent Studies of Rus' Relations with the Tatars of the Jochid Ulus // Золотоордынское обозрение. 2020. Т. 8, № 1. C. 32-50. DOI: $10.22378 / 2313-6197.2020-8-1.32-50$

Сведения об авторе: Чарльз Дж. Гальперин - внештатный научный сотрудник Российского и Восточно-Европейского института, Университет Индианы, Блумингтон (Блумингтон, Индиана, США). E-mail: chalperi@iu.edu

Поступила 25.12.2019 Принята к публикащии 27.02.2020

Опубликована 29.03.2020 